\title{
Synaptic Actions of Identified Peptidergic Neuron R15 in Aplysia. II. Contraction of Pleuroabdominal Connectives Mediated by Motoneuron L7
}

\author{
A. Alevizos, ${ }^{1}$ K. R. Weiss, ${ }^{2, a}$ and J. Koester ${ }^{2}$ \\ Center for Neurobiology and Behavior, 'Department of Physiology and Cellular Biophysics and 2Department of Psychiatry, \\ College of Physicians and Surgeons, Columbia University, New York, New York 10032
}

\begin{abstract}
The purpose of this study was to determine the synaptic actions of the bursting peptidergic neuron R15 in Aplysia. R15 is known to be excited by the neuroendocrine bag cells, which trigger egg laying. In the two companion papers, we show that R15 mediates some of the effects of the bag cells on respiratory and reproductive organs. In this paper, we demonstrate that $R 15$ excites L7, a multimodal motoneuron located in the abdominal ganglion. Although L7 excites several types of muscle fibers as well as neurons, the excitation of L7 by R 15 is probably strong enough to cause contraction only of the sheath muscle of the pleuroabdominal connectives, which has an exceptionally low threshold for activation. The excitatory actions of R15 on L7, which desensitize profoundly, appear to be mediated by $R 15 \alpha 1$ peptide. The synaptic action of $R 15$ on $L 7$ and on the respiratory pumping system (Alevizos et al., 1991a) can be fully expressed only if $\mathbf{R} 15$ is first silenced for 2 hr by injection of hyperpolarizing current. A similar protocol for eliminating desensitization may prove to be generally useful for revealing the synaptic actions of other spontaneously active neurons that have rapidly desensitizing postsynaptic actions.
\end{abstract}

The goal of this study was to determine the synaptic actions of the neurosecretory bursting cell R15 of Aplysia, in order to gain insight into its physiological function. Evidence presented in this series of three papers suggests that R15 is involved in mediating egg-laying behavior.

Aplysia, which is a non-self-fertilizing hermaphrodite, lays eggs in large masses containing up to $10^{6}$ fertilized eggs. Its egglaying behavior is stereotyped, involving a complex sequence of head and body movements (Cobbs and Pinsker, 1982a,b). The bilaterally symmetrical neuroendocrine bag cell clusters of the abdominal ganglion play a key role in coordinating this complex behavior. Inputs that presumably originate in the cerebral and pleural ganglia (Painter et al., 1988; Brown et al., 1989) depolarize the bag cells, causing them to fire in a synchronous discharge that releases a family of peptides, egg-laying

\footnotetext{
Received Apr. 13, 1990; revised Dec. 10, 1990; accepted Dec. 13, 1990.

We thank M. Skelton for critically reviewing an earlier draft of this paper, and Dr. Sam Schacher for culturing R 15 neurons for us. This work was supported by NIH Grants NS14385 and GM32099, National Institute of Mental Health Grant MH36730, an NIH BRSG grant, and the Klusk Foundation.

Correspondence should be addressed to Dr. J. Koester, Center for Neurobiology and Behavior, The New York State Psychiatric Institute, 722 West 168 Street, New York, NY 10032.

a Present address: Mount Sinai School of Medicine, New York, NY 10029.

Copyright $(C) 1991$ Society for Neuroscience 0270-6474/91/111275-07\$03.00/0
}

hormone (ELH) and the $\alpha-, \beta$-, and $\gamma$-bag-cell peptides (BCPs; Rothman et al., 1983; Mayeri et al., 1985; Sigvardt et al., 1986; Brown and Mayeri, 1989). ELH causes release of the oocytes from the ovotestis, and ELH and the BCP peptides modulate the activity of various neurons in the abdominal and buccal ganglia (Stuart and Strumwasser, 1980; Mayeri and Rothman, 1985; Brown and Mayeri, 1989). Although none of the central actions of the bag cells have been related to the control of any specific feature of egg-laying behavior, it generally is assumed that they help to coordinate the different motor outputs that control egg-laying behavior.

One of the most robust central effects of the bag cell burst is strong excitatory modulation of R15 bursting (Branton et al., 1978). In the two companion papers (Alevizos et al., 1991a,b), it is demonstrated that $\mathrm{R} 15$ increases the frequency of respiratory pumping and of peristalsis of the large hermaphroditic duct. These effects were shown to be mimicked by $\mathrm{R} 15 \alpha 1$ peptide, one of the three neuropeptides known to be synthesized by R15 (Weiss et al., 1989). In this paper, we demonstrate that $\mathrm{R} 15$ and The $\mathrm{R} 15 \alpha 1$ peptide also excite the multimodal motoneuron $\mathrm{L} 7$ in the abdominal ganglion.

L7 is unique among identified motoneurons in Aplysia in terms of its widespread effector field. It sends axons to the periphery via the branchial, pericardial, genital, and siphon nerves, innervating several types of effector organs, synapsing not only onto muscle cells but also onto peripheral neurons. L7 is best known for its role as an excitatory motoneuron for the gill and siphon (Kupfermann and Kandel, 1969; Peretz, 1969; Carew et al., 1974; Perlman, 1979) and for exciting the gill motoneurons in the branchial ganglion (Kurokawa and Kuwasawa, 1985). It has been shown to contribute to the mediation of the gill and siphon defensive withdrawal reflex elicited by tactile stimuli (Kupfermann et al., 1974; Perlman, 1979). In addition, L7 directly excites sheath-contracting muscle fibers in the pleuroabdominal connectives (Umitsu et al., 1987), cardiac muscle of the auricle, and vasoconstrictor muscle of the abdominal aorta (Alevizos et al., 1989a). The behavioral functions of L7, other than its contribution to defensive withdrawal, have remained uncertain. The results presented in this paper suggest that L7 may play a role in the mediation of egg-laying behavior.

Some of these results have been described in a preliminary communication (Alevizos et al., 1989b).

\section{Materials and Methods}

Recording techniques. Standard electrophysiological techniques were used, as described in the preceding paper (Alevizos et al., 1991a). As reported in that paper, the following "nondesensitizing washing protocol" was 
employed in order to prevent desensitization of the synaptic actions of R15 when it bursts spontaneously: (1) During dissection and mounting of the ganglion in the recording chamber, it was bathed in a high- $\mathrm{Mg}^{2+} /$ low-Ca ${ }^{3+}$ saline to prevent transmitter relcase. (2) Before the ganglion was washed with standard saline [artificial seawater (ASW)], R15 was impaled and prevented from firing by injecting hyperpolarizing current. (3) R15 was kept hyperpolarized for $2 \mathrm{hr}$ before releasing it to burst spontaneously, at which time its postsynaptic actions were observed. R15 also was kept hyperpolarized throughout experiments in which the actions of $\mathrm{R} 15 \alpha 1$ peptide were tested, to prevent chronic desensitization. In a few experiments, the soma of $\mathrm{L} 7$ was tied off from its processes in the ganglion in order to test whether the effects of R $15 \alpha 1$ peptide on the soma were mediated directly. The proximal axon was ligated with a fine thread teased out from a piece of silk suture. R15 $\alpha 1$ peptide was purchased from Peninsula Laboratories (Belmont, CA) as "neuron-specific peptide." R15 $\beta$ peptide (Weiss et al., 1989) was synthesized by the Howard Hughes Medical Institute Protein Center Core Facility at Columbia University.

Contraction of the pleuroabdominal connectives was measured visually using a compound microscope with a graticule in one eyepiece. A piece of suture was tied loosely around one connective, about $10 \mathrm{~mm}$ from the abdominal ganglion. A pin was placed in the elastomer bottom of the chamber as a reference point at a position $6 \mathrm{~mm}$ closer to the ganglion. Contraction of the connective was measured as the decrease in the distance between the ligature and the pin. The animals used in these experiments weighed about $100 \mathrm{gm}$.

Cell culture. Cells from the abdominal ganglion of Aplysia were cultured according to the method developed by Schacher and Proshansky (1983). Abdominal ganglia were dissected from animals weighing 1-3 $\mathrm{gm}$ and bathed for $2.5 \mathrm{hr}$ in a $1 \%$ solution of protease type IX (Sigma; St. Louis, MO) at $34^{\circ} \mathrm{C}$. After incubation, the ganglia were washed extensively with L1 5 culture medium (Flow Laboratories, McLean, VA) supplemented with salts (to match marine medium conditions) and with penicillin $(10,000 \mathrm{U} / \mathrm{ml})$ and streptomycin $(10 \mathrm{mg} / \mathrm{ml})$, pinned to the Sylgard (Dow Corning) bottom of a Petri dish, and desheathed. Cells were identified by position, size, and color. They were pulled out of the ganglion by means of sharp glass microelectrodes and transferred via a glass micropipette to polylysine-coated culture dishes containing modified L15 medium and filtered $(0.2-\mu \mathrm{m}$ sterile filter; Acrodisc, Gelman Sciences) Aplysia hemolymph (1:1). Culture dishes were kept in an $18^{\circ} \mathrm{C}$ incubator for 3-4 d until use. On the second day, the bathing medium was replaced with fresh solution.

Data presentation and statistical analysis. All data are given as mean values \pm the standard error of the mean (SEM). All statistical analyses of the results were made using a two-tailed $t$ test with a cutoff of $p=$ 0.05 for comparing the difference between means.

\section{Results}

$R 15$ excites $L 7$

After characterizing the modulatory effects of R15 on the frequency of respiratory pumping (Alevizos et al., 1991a), other cells of the abdominal ganglion were tested as possible followers of R 15 by using the nondesensitizing washing protocol described above. Among the cells tested were the left caudal quadrant (LCQ) neurons, some of which receive synaptic input from $R 15$ (Brown and Mayeri, 1987), including the $\mathrm{LB}_{\mathrm{vc}}$ vasoconstrictor cells, which are excited by R15 firing (Alevizos and Koester, 1986). These synaptic actions were reported to be highly variable between preparations in these earlier studies. In spite of our precautions to reduce chronic desensitization, these synaptic effects remained highly variable in this study. In only 2 out of $12(17 \%)$ preparations did cells of the LCQ respond to R15 with excitation. As reported by Brown and Mayeri (1987), we found that the excitation followed the R 15 burst pattern, did not decay with repetition, and was maintained throughout the experiment. In response to $\mathrm{R} 15$ firing, the $\mathrm{LB}_{\mathrm{vc}}$ cells were mostly inhibited by the indirect inhibitory input they receive from the cells of the $\mathrm{R} 25 / \mathrm{L} 25$ network, which is excited by $\mathrm{R} 15(N=6)$. The weak excitation occasionally seen in earlier studies when the nondesensitizing protocol was not used (Alevizos and Koester,
1986) was therefore masked by this indirect inhibitory input. $\mathrm{R} 15$ is known to synthesize three neuropeptides: $\mathrm{R} 15 \alpha 1, \mathrm{R} 15 \beta$, and $\mathrm{R} 15 \gamma$ peptides. Neither the R $15 \alpha 1$ peptide nor the R15 peptide affected the $\mathrm{LB}_{\mathrm{vC}}$ or the LCQ cells at concentrations as high as $2 \times 10^{-5} \mathrm{M}$. Synthetic R15 $\gamma$ peptide was not available for testing.

We also surveyed a variety of other identified cells and cell types in the abdominal ganglion (described by Koester and Kandel, 1977; Alevizos et al., 1989c). Neither R15 nor the R15 $\alpha 1$ or $\mathrm{R} 15 \beta$ peptides elicited any response in the gill motoneurons $\mathrm{L}_{\mathrm{G} 1}, \mathrm{~L} 9_{\mathrm{G} 2}, \mathrm{LD}_{\mathrm{G} 1}, \mathrm{LD}_{\mathrm{G} 2}$, and $\mathrm{RD}_{\mathrm{G}}$; the siphon $\mathrm{LB}_{\mathrm{S}}$ and $\mathrm{LD}_{\mathrm{S}}$ motoneurons; cells of the RB cluster; cells L10, L12, and L13; the RG cells; and sensory cells from the LE cluster. The only consistent effect of firing R15 was on L7.

The motoneuron $L 7$ responded to bursting of $R 15$ in a manner qualitatively similar to that of the cells of the R25/L25 network. That is, $\mathrm{R} 15$ generated a long-lasting excitation of $\mathrm{L} 7$ that gradually decreased (Fig. 1 $A$ ). L7 typically begins to fire spontaneously as soon as the anesthesia is washed out. However, in $80 \%$ of the 49 preparations used, L7 became silent within $1 \mathrm{hr}$ after the beginning of washout and remained silent for as long as R15 was silent. Releasing R 15 from hyperpolarization elicited a strong tonic depolarization in $\mathrm{L} 7$ and a firing rate that averaged 0.54 $\mathrm{Hz}(N=17)$ for the first $10 \mathrm{~min}$ of L7's excitation.

\section{$R 15 \alpha 1$ peptide may mediate the effect of $R 15$ on $L 7$}

The excitation of $\mathrm{L} 7$ by $\mathrm{R} 15$ could be mimicked by the R $15 \alpha 1$ peptide (Fig. $1 B$ ). We used a variety of protocols that reduce or eliminate polysynaptic transmission to test whether the effect of $\mathrm{R} 15 \alpha 1$ peptide on $\mathrm{L} 7$ is direct and to determine whether the connection from $\mathrm{R} 15$ to $\mathrm{L} 7$ is monosynaptic or is mediated via interneurons. Application of the R $15 \alpha 1$ peptide while the ganglion is bathed in a solution containing tetrodotoxin (TTX) produces an excitatory effect on L7 (Fig. $2 A$ ). Firing R15 in the same TTX solution also elicits a slow depolarization in L7 (Fig. $2 B$ ). Similar long-lasting, slow depolarizations are produced by either R15 firing or the R15 1 peptide when the ganglion is bathed in a high-divalent-cation solution (Fig. $2 F, G$ ). By ligating the proximal axon, we deprived L7 of all synaptic inputs that could indirectly excite the soma, but the peptide still produced excitation when applied to the tied-off soma (Fig. 2D). Application of $\mathrm{R} 15 \alpha 1$ peptide also produced long-lasting excitation of $\mathrm{L} 7$ cells that were grown in primary cell culture, in isolation from other synaptic inputs (Fig. $2 C$ ). In experiments in which L7 had been cocultured in close apposition with R15, firing R 15 by injecting current into the cell body caused a long-lasting excitation in L7 (Fig. 2E). Some Aplysia neurons are known to form nonspecific chemical connections in culture (Camardo et al., 1983), so the specificity of the R15-L7 connection in culture was tested by coculturing $\mathrm{R} 15$ with $\mathrm{L} 11(N=2)$, a cell that does not respond to $\mathrm{R} 15$ in the ganglion. Firing $\mathrm{R} 15$ or applying the R15 $\alpha 1$ peptide had no effect on L11 in culture, suggesting that the R15-L7 connection and the response to L7 to the peptide in culture are probably specific. These data support the conclusion that the R15-L7 synaptic connection is direct, that $\mathrm{R} 15 \alpha 1$ peptide acts directly on $\mathrm{L} 7$, and that the R $15 \alpha 1$ peptide mediates, at least in part, the synaptic actions of R 15 on $\mathrm{L} 7$.

When successive 10-min periods of spontaneous $\mathrm{R} 15$ bursting were separated by an interval of 20-30 $\mathrm{min}$, the second L7 response was completely suppressed (Fig. $3 A, B$ ). Both the tonic depolarizing component of the response and the increased rate of firing of L7 were absent during the second R 15 firing period 


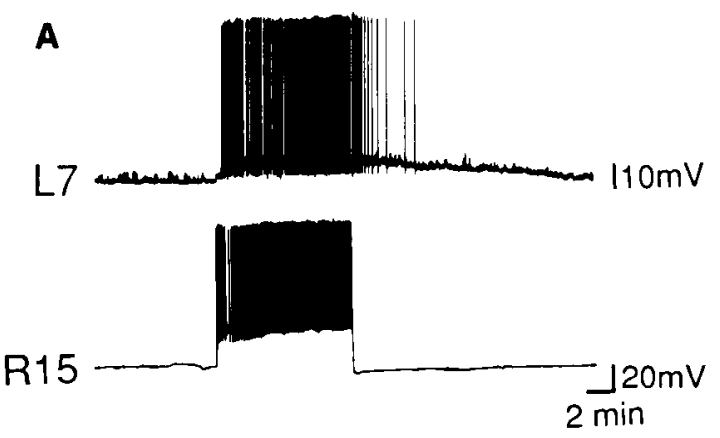

$\mathbf{B}$

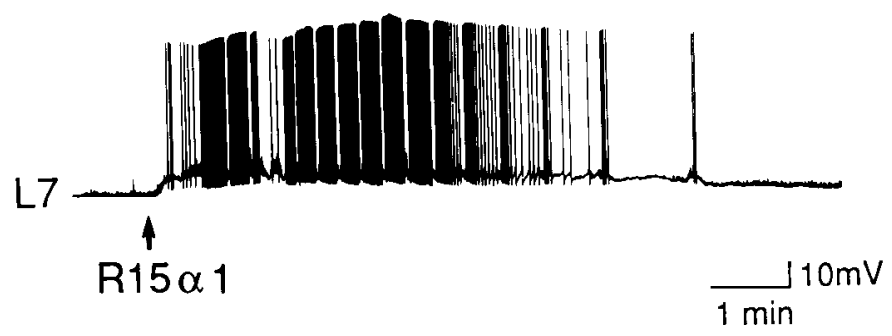

Figure 1. R15 and R15 1 peptide excite motoneuron L7. Allowing R15 to burst spontaneously for 10 min following a 2-hr period of hyperpolarization produces long-lasting excitation of $\mathrm{L} 7$, which outlasts $\mathrm{R} 15$ bursting. (The compressed time scale obscures the intervals between bursts.) Application of R15 1 peptide mimicks the effect of R15 on L7. A 50- $\mu$ l bolus of $5 \times 10^{-6} \mathrm{M}$ peptide was applied near the isolated ganglion while the preparation was continuously superfused with ASW at $1-1.5 \mathrm{ml} / \mathrm{min}$.

(Fig. 3A). In a separate experiment, the peak response of $\mathrm{L} 7$ to R 15 activity recovered to $91 \%$ of its initial value when the interval between successive releases of R 15 was prolonged to $40 \mathrm{~min}$. However, the excitatory effect of R15 on L7 decayed faster during the second firing period of R15, even though there was a slight increase in the number of spikes in R15 during the second $\mathrm{R} 15$ firing period ( $N=2$; data not shown).
The decrement in responsiveness of $\mathrm{L} 7$ to $\mathrm{R} 15$ may be caused by activity dependence of the $\mathrm{R} 15$ to $\mathrm{L} 7$ connection, refractoriness of $\mathrm{L} 7$ firing, presynaptic depression, or desensitization. The effects of R15 on the R25/L25 network also decrease with repetition, an effect that has been attributed to desensitization of the postsynaptic receptors activated by $\mathrm{R} 15 \alpha 1$ peptide, the putative transmitter of R15 (Alevizos et al., 1991a). A similar
A

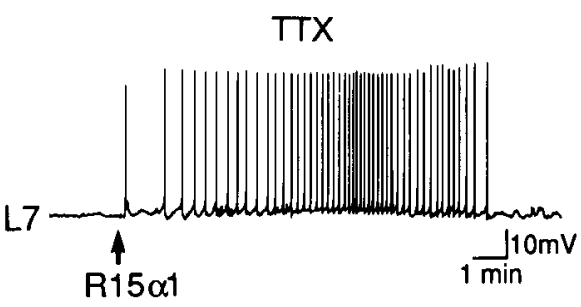

C

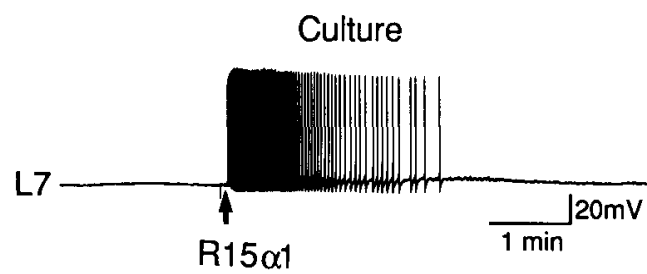

E
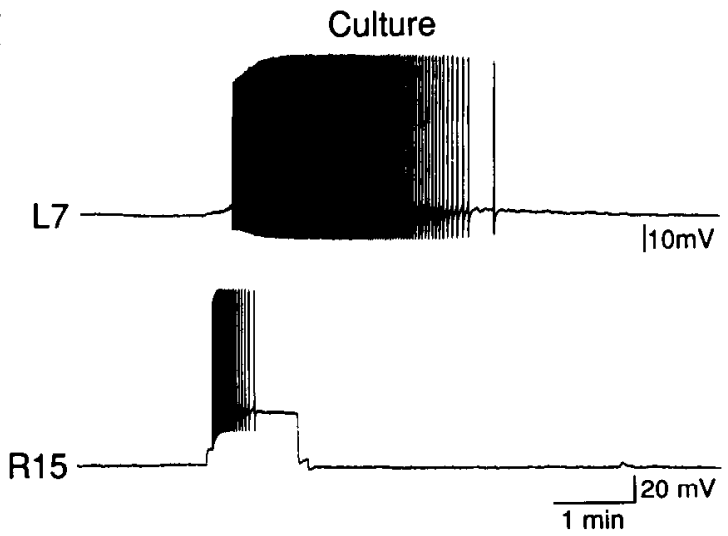

B

$\pi \mathrm{X}$
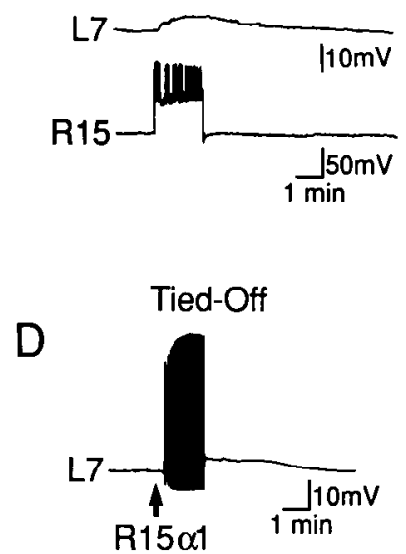

$\mathrm{F}$

$3 \times \mathrm{Ca} / \mathrm{Mg}$

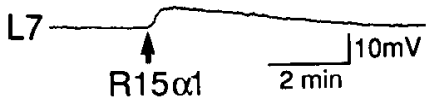

$G$

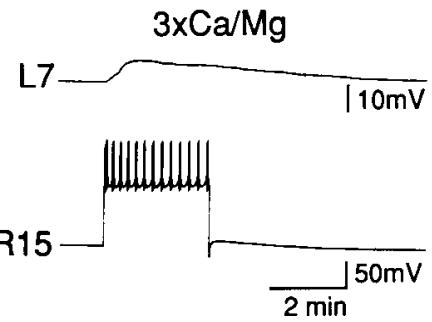

Figure 2. $\mathrm{R} 15$ and the $\mathrm{R} 15 \alpha 1$ peptide act directly on L7. $A$, Adding R15 1 peptide, in the presence of $3 \times 10^{-5} \mathrm{M}$ TTX to reduce polysynaptic pathways, excites L7. R15 was kept hyperpolarized throughout the experiment $(N=$ 2). $B$. Firing R 15 for 2 min by injecting DC current into the cell body while the ganglion is bathed in TTX $\left(3 \times 10^{-5}\right.$ $\mathrm{M})$ produces a slow, long-lasting depolarization of $\mathrm{L} 7(N=2)$. C, R15al peptide applied on an isolated $\mathrm{L} 7$ cell grown in primary cell culture produces a longlasting excitation of $\mathrm{L} 7(N=7) . D$, The $\mathrm{R} 15 \alpha 1$ peptide produces a long-lasting excitation of an L7 soma that was tied off with a silk thread $(N=3)$. $E, \mathrm{R} 15$ was cocultured in close apposition with L7 in primary cell culture. Firing R 15 by current injection into its cell body elicits a long-lasting excitation in $\mathrm{L} 7(N$ $=3$ ). $F$, Application of a bolus of R $15 \alpha 1$ peptide near the ganglion, while the preparation is superfused continuously with a solution of high divalent cations ( $3 \times$ normal $\mathrm{Ca}^{2+}$ and $\mathrm{Mg}^{2+}$ concentrations) to reduce polysynaptic pathways, produces long-lasting excitation of $\mathrm{L} 7$ $(N=5)$. $G$, Allowing $\mathrm{R} 15$ to burst spontaneously after a 2-hr hyperpolarization, while the ganglion is bathed in a solution of high divalent cations, produces a long-lasting depolarization of L7 $(N=5)$. The peptide was applied in a $50-\mu l$ bolus of $5 \times 10^{-6} \mathrm{M}$ in all cases, except $F$, where the concentration was $2 \times 10^{-5} \mathrm{M}$. 
A
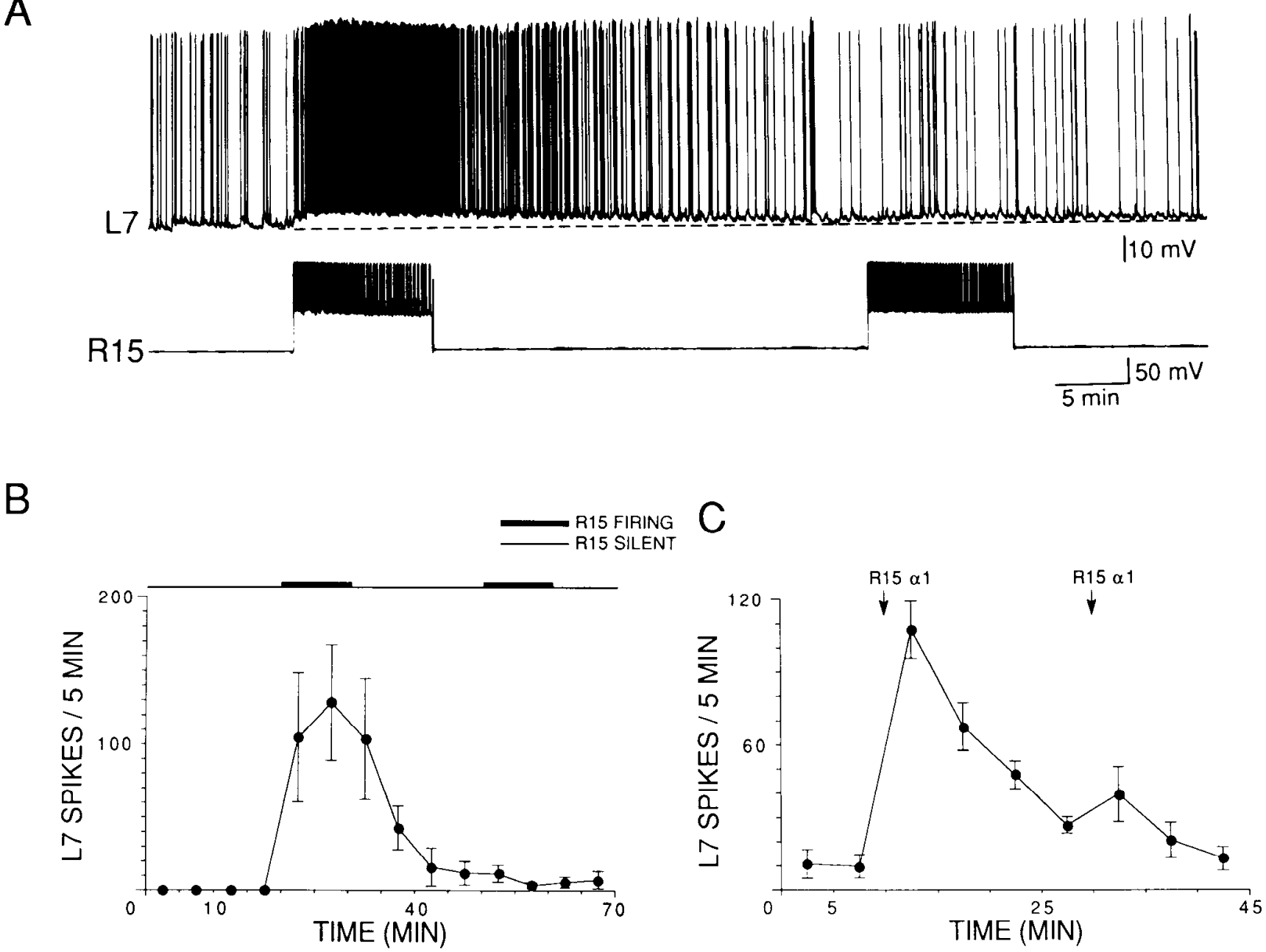

Figure 3. The effect of R15 and R15 $\alpha 1$ peptide on L7 decays with repctition. A, Allowing R15 to burst spontaneously for 10 min after a 2-hr hyperpolarization produces a long-lasting excitation of motoneuron L7. Releasing R 15 from hyperpolarization 30 min later produces a much weaker depolarization and increase in L7 firing. The number of spikes in R15 increased by $25 \%$ during the second firing period compared to the first. $B$, Allowing R 15 to fire spontaneously for $10 \mathrm{~min}$ after a 2-hr hyperpolarization elicits a long-lasting excitation in L7. Releasing R15 for another 10 min period, $20 \mathrm{~min}$ after the end of the first firing period, does not produce any significant effect on $\mathrm{L} 7(N=4 ; \pm \mathrm{SEM}) . C$, R15 $\alpha 1$ peptide mimicks the effect of R15 on L7. Application of the peptide (a $50-\mu$ l bolus of $6 \times 10^{-6} \mathrm{M}$ ), while the ganglion was superfused continuously with ASW at a rate of $1-1.5 \mathrm{ml} / \mathrm{min}$, produces long-lasting excitation of $\mathrm{L} 7$. A second application of the peptide at the same concentration, $20 \mathrm{~min}$ later, has no significant effect on $\mathrm{L} 7(N=4 ; \pm$ SEM).

mechanism appears to contribute to decrement at the R15-L7 synapse, as successive applications of the $\mathrm{R} 15 \alpha 1$ peptide resulted in a decreased responsiveness of L7 (Fig. 3C).

Two experiments were performed to test whether spike activity in $\mathrm{L} 7$ is necessary for the decrease in responsiveness of L7 to R15. To test for activity dependence of the R15-L7 connection, $\mathrm{L} 7$ was fired by injecting current $(5 \mathrm{nA})$ into its soma for $10 \mathrm{~min}$ before allowing R15 to burst. The response of $\mathrm{L} 7$ to $\mathrm{R} 15$ was not significantly different from the response produced when $\mathrm{L} 7$ was not prefired (Fig. 4A). To test if the decremental response of $\mathrm{L} 7$ to both $\mathrm{R} 15$ and $\mathrm{R} 15 \alpha 1$ peptide could be due to accommodation in L7, another control experiment was performed in which $\mathrm{L} 7$ was fired by DC current injection (12 $\mathrm{nA})$ into the cell body for $30 \mathrm{~min}$. L7 exhibited no appreciable accommodation in this experiment, even when it fired at rates fivefold higher than those it achieved in response to R 15 bursting (Fig. $4 B$ ). These data suggest that the decay of the $\mathrm{L} 7$ re- sponse to $\mathrm{R} 15$ resulted from desensitization and, perhaps, from presynaptic depression.

Cross-desensitization experiments were performed to test whether R15 and the R15 $\alpha 1$ peptide act on $\mathrm{L} 7$ through the same receptor or postreceptor mechanism. Successive applications of the $R 15 \alpha 1$ peptide resulted in a decrease of the response of $L 7$, which also became unresponsive to R15 (Fig. $5 A$ ). Similarly, prolonged firing of R15 led to a decrement of the response in $\mathrm{L7}$, as well as to a failure of $\mathrm{L} 7$ to respond to application of $\mathrm{R} 15 \alpha 1$ peptide at concentrations that normally produce a substantial effect on $\mathrm{L} 7$ (Fig. $5 B$ ). These results suggest that the $\mathrm{L} 7$ responses to R15 and to the R15 1 peptide are mediated through the same receptor or the same postreceptor mechanism. Moreover, they are consistent with the hypothesis that the decay of L7's response to R15 results from desensitization, though we cannot rule out the possibility that presynaptic deprcssion also may be a factor. 
A

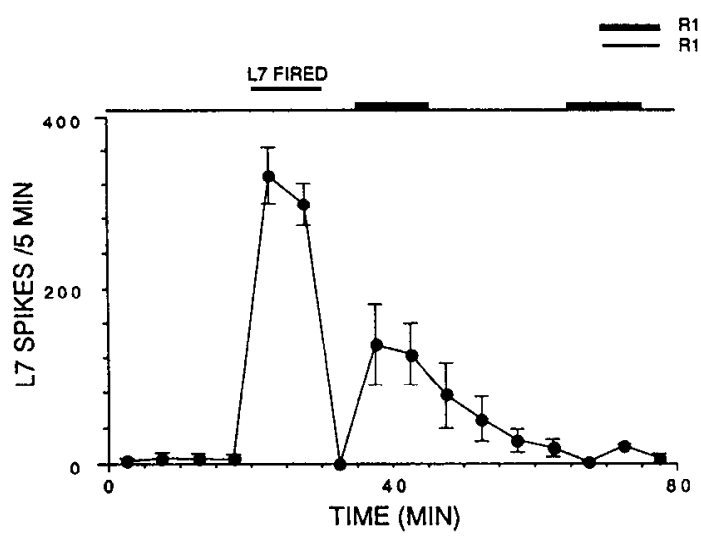

B

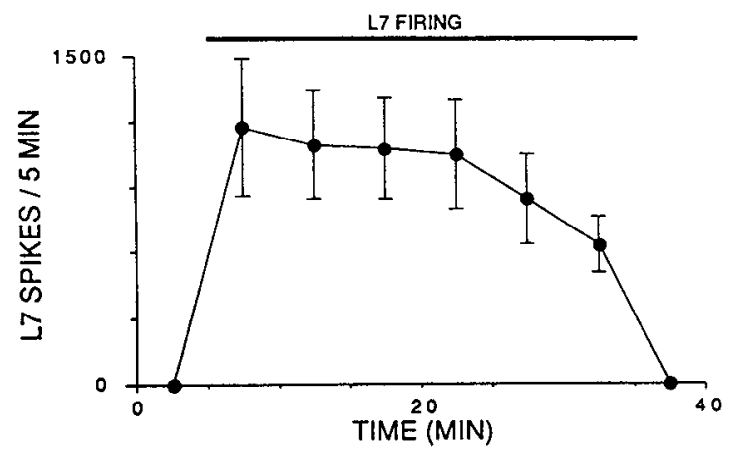

Figure 4. The waning of the effect of R15 on $\mathrm{L} 7$ (Fig. $3 B$ ) is not due to activity in $\mathrm{L} 7$ or to accommodation of L7. $A$, Prefiring $\mathrm{L} 7$ by current injection into its cell body (DC current, $5 \mathrm{nA}$ for $10 \mathrm{~min}$ ) just before R 15 was released from hyperpolarization for $10 \mathrm{~min}$, after a $2-\mathrm{hr}$ hyperpolarization period, did not reduce the excitatory effect of R15 on L7. The response of $L 7$ to $R 15$ firing was not significantly different from the response observed without prefiring L7. A second release of R15 20 min later had no significant effect on L7 activity. B, Firing L7 by current injection into the cell body (DC current, $12 \mathrm{nA}$ ) for $30 \mathrm{~min}$, at rates much higher than the rates $\mathrm{L} 7$ assumes upon $\mathrm{R} 15$ firing, produces only modest accommodation. Error bars represent SEM.

A variety of experiments were performed to test for possible inputs or substances that might influence the R15-L7 connection. The R $15 \beta$ peptide had no effect on L7, either when applied by itself or in combination with the R $15 \alpha 1$ peptide (data not shown; $N=3$ ). The modulatory effect of $\mathrm{R} 15$ on $\mathrm{L} 7$ was quantitatively and qualitatively the same whether or not the abdominal ganglion was connected to the head ganglia via the pleuroabdominal connectives (data not shown; $N=2$ ). In addition, the spontaneous synaptic input that $\mathrm{L} 7$ receives from interneuron XIII was not modulated during R15 firing.

\section{Excitation of $L 7$ by $R 15$ causes contraction of the connectives}

Several experimental protocols were tried in an effort to determine the functional significance of the excitation of $\mathrm{L} 7$ by R 15 . Firing rates of $\mathrm{L} 7$ elicited by $\mathrm{R} 15$ bursting were too low to generate gill and siphon contractions. The interactions of $\mathrm{L} 7$ with other identified motoneurons that converge onto its widespread effector field also were tested. It had been shown previously that $\mathrm{L} 7$ firing produces a synergistic effect on the gill contraction elicited by $\mathrm{RD}_{\mathrm{G}}$ (Leonard et al., 1988). The result of our experiment was negative, however; firing $\mathrm{L} 7$ at the low frequencies produced by $\mathrm{R} 15$ bursting did not enhance the $\mathrm{RD}_{\mathrm{G}^{-}}$ elicited gill contraction $(N=2)$. In addition, we tested whether
A

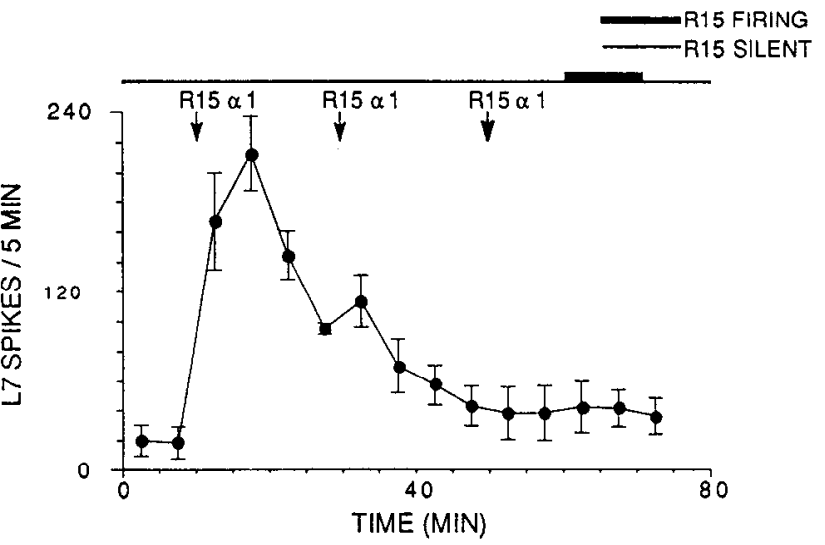

B

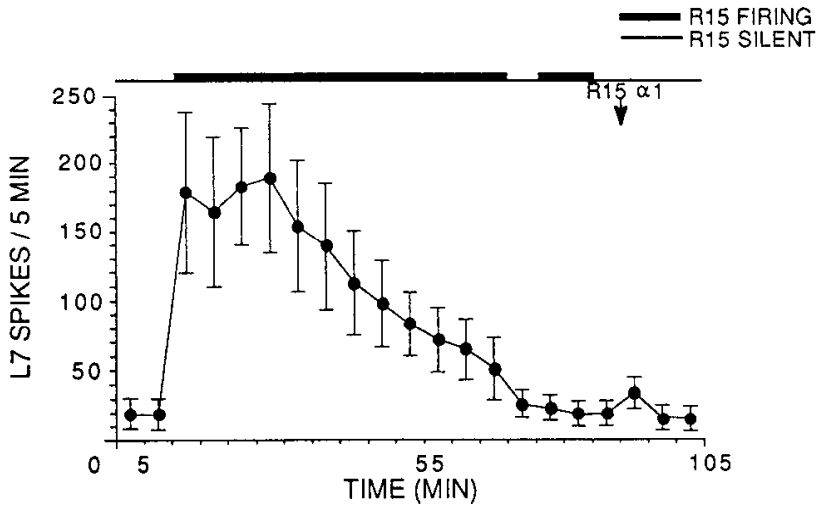

Figure 5. $\mathrm{R} 15$ and the $\mathrm{R} 15 \alpha 1$ peptide act on $\mathrm{L} 7$ through the same receptor or postreceptor mechanism. $A$, Two successive applications of the $\mathrm{R} 15 \alpha 1$ peptide render $\mathrm{L} 7$ insensitive to a third identical application of the peptide (R15 has been kept hyperpolarized from the start of the experiment). Allowing R 15 to burst spontaneously for $10 \mathrm{~min}$ after the third peptide application results in no effect on L7, due to cross-desensitization. Peptide was applied in a 50- $\mu$ l bolus of $2 \times 10^{-5} \mathrm{M}(N=4)$. $B$, Releasing R 15 from hyperpolarization for $60 \mathrm{~min}$ after a 2 -hr hyperpolarization period produces a long-lasting excitation of L7. L7 becomes insensitive to a second 10 -min firing period of $R 15$, and does not respond to R15al peptide (50 $\mu$ l of $6 \times 10^{-6} \mathrm{M} ; N=4$ ). Error bars represent SEM.

the tonic firing of $\mathrm{L} 7$ can modulate the $\mathrm{L} 7$-elicited gill and heart contractions. It had been reported earlier that tonic background firing of some gill and siphon motoneurons enhances the contractions elicited by those motoneurons (Jacklet and Rine, 1977; Frost, 1987). However, the low firing rate that $L 7$ achieved in response to R15 firing did not potentiate its motor effects on the gill and heart when L7 was subsequently fired by current injection at higher frequencies $(N=4)$.

The only positive result we observed when $\mathrm{L} 7$ fired in response to R15 bursting came during visual observation of the pleuroabdominal connectives. Each of the bilaterally symmetrical connectives consists of a central core of axons surrounded by a sheath of muscle and connective tissue, which also contains a blood vessel. $\mathrm{L} 7$ was found to produce a contraction of the connectives at the firing rates it reaches in response to $R 15$ bursting. The effect of $\mathrm{L} 7$ on connective contraction decreases as L7's response to $\mathrm{R} 15$ desensitizes (Fig. 6A). Hyperpolarizing L 7 by current injection during R 15 firing prevents contraction of the connective, and firing $\mathrm{L} 7$ by current injection after the R15 bursting period causes connective contraction (Fig. 6B). 
A

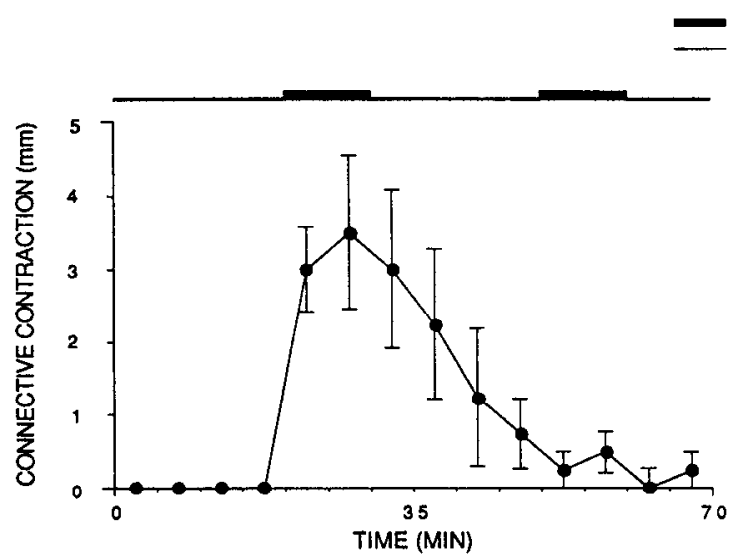

B

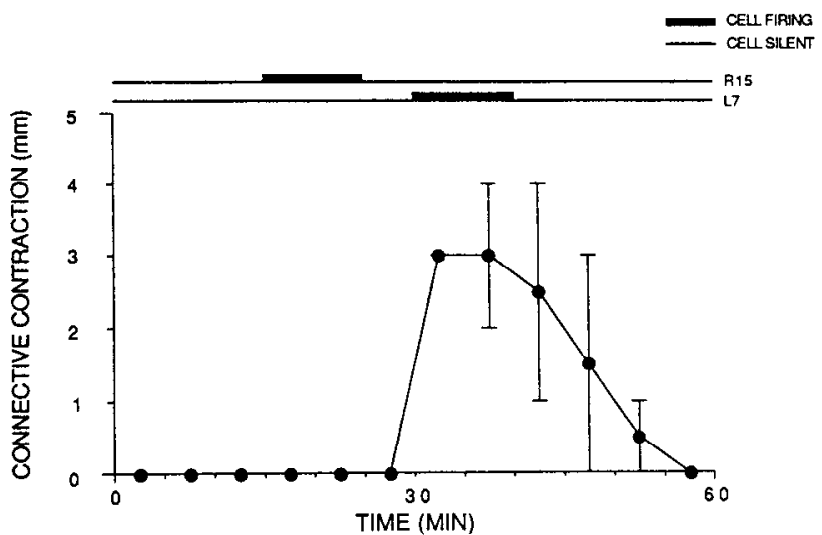

Figure 6. Firing $\mathrm{L} 7$ in response to $\mathrm{R} 15$ bursting contracts the pleuroabdominal connectives. $A$, Allowing $\mathrm{R} 15$ to fire spontaneously for 10 min after a 2-hr period of hyperpolarization excites L7, causing contraction of the pleuroabdominal connectives. A second firing period in $\mathrm{R} 15$ after 20 min produces no effect on $\mathrm{L} 7$ and no connective contraction $(N=4)$. $B$, If $\mathrm{L} 7$ is prevented from firing by injection of hyperpolarizing current, it does not fire when R15 is released from hyperpolarization, and no connective contraction is elicited. Firing L7 by injecting depolarizing current into the cell after the end of R 15 firing elicits connective contraction. A 5-nA DC current, injected into $\mathrm{L} 7$ for $10 \mathrm{~min}$, produced $285 \pm 49$ spikes in the first $5 \mathrm{~min}$, a firing frequency that is approximately double the frequency elicited by spontaneous bursting of R 15 $(N=2)$. Error bars represent SEM.

These data are consistent with the hypothesis that $\mathbf{L} 7$ activity is necessary and sufficient to mediate the contraction of the connectives produced by bursting of R 15 .

\section{Discussion}

$R 15 \alpha 1$ peptide may mediate the excitatory effect of $R 15$ on $L 7$ Four types of data bear on the question of the identity of the transmitter used by R15 to excite L7: (1) R15 is known to synthesize the R15 $\alpha 1$ peptide (Weiss et al., 1989), and the actions of R15 and of the R $15 \alpha 1$ peptide on $\mathrm{L} 7$ are qualitatively similar, are long lasting, and decrement readily. (2) Both R15 and exogenously applied R $15 \alpha 1$ peptide appear to act directly on L7, because both effects persist under conditions in which polysynaptic activity in the ganglion is greatly reduced. (3) The excitatory actions of $\mathrm{R} 15$ and of the R $15 \alpha 1$ peptide cross-desensitize, suggesting that R 15 and the R $15 \alpha 1$ peptide may act on the same receptor or second-messenger system. (4) The other $\mathrm{R} 15$ peptide that is available in synthetic form, $R 15 \beta$ peptide, was without effect on $\mathrm{L} 7$ activity. These data are all consistent with the hypothesis that, like the excitatory actions of R15 on the R25/L25 network, the excitation of L7 by R15 is mediated in part by the release of $R 15 \alpha 1$ peptide.

\section{The functional significance of desensitization of R15's synaptic actions}

The central excitatory actions of R 15 on the R25/L25 network (Alevizos et al., 1991a) and on L7 both desensitize profoundly after several min of spontaneous R15 bursting. These synaptic actions, which appear to be mediated by $\mathrm{R} 15 \alpha 1$ peptide, can be revealed only by using the nondesensitizing washing protocol. In this protocol, R15 is silenced for $2 \mathrm{hr}$ by injecting hyperpolarizing current during and after washout of the anesthetic, to allow the decay of any residual postsynaptic desensitization before R15 is allowed to burst. Only when such precautions are taken is it possible to observe the postsynaptic actions of R15. If other spontaneously active neurons produce similar longlasting desensitization of their postsynaptic targets, their synaptic actions may be masked in the same way that R15's have been for the past 30 years. It would be interesting to use this protocol to look for possible synaptic actions of other spontaneously active cells in Aplysia, as well as in other animals.

The question arises as to how a continuously bursting neuron such as R15, which has synaptic actions that rapidly desensitize, can ever exert a physiological action. In the case of $R 15$, the answer lies in the fact that R15 is normally silent in the intact animal, presumably going into its bursting mode only episodically (Alevizos et al., 1991a). In this respect, the desensitization produced by $\mathrm{R} 15 \alpha 1$ peptide resembles that observed with certain hypothalamic hormones. For example, luteinizing hormone-releasing hormone (LHRH) must be released episodically to elicit long-term effects, because continuous exposure to high levels of LHRH desensitizes the gonadotrophs of the anterior hypophysis (Belchetz et al., 1978).

\section{Functional significance of the excitation of $R 15$ by $L 7$}

Of several identified neurons tested, only the multimodal motoneuron $\mathrm{L} 7$ responded consistently to $\mathrm{R} 15$ and to the $\mathrm{R} 15 \alpha 1$ peptide. This motoneuron has motor effects on a variety of effector organs, including siphon, gill, heart, abdominal artery, kidney, branchial ganglion gill motoneurons, nerve and connective sheaths, and the connective tissue capsule covering the abdominal ganglion. Umitsu et al. (1987) have shown that the effector most sensitive to $\mathrm{L} 7$ is the sheath of the pleuroabdominal connectives, which can respond to a single action potential in L7. In our experiments, none of the other tissues responded to the activation of $\mathrm{L} 7$ by $\mathrm{R} 15$. In the intact animal, some of these synaptic actions of $L 7$ may potentiate or sum with other inputs, allowing $\mathrm{L} 7$ to have a variety of other motor effects when it is excited by R15. Alternatively, only the L7 connection to the connectives may be functionally important.

A hypothesis that describes the possible functional significance of the activity elicited in $\mathrm{L} 7$ by R 15 bursting is suggested by three observations: (1) The connective tissue capsule of the abdominal ganglion has vascular spaces and also terminals of the bag cells, thereby acting as a neurohemal organ (Coggeshall, 1967). (2) The neuropeptides that are released by the bag cells appear to be differentially distributed to different release sites. Sossin et al. (1990) found that the neurohormone ELH, which acts at sites throughout the body and is distributed in the general circulation, is present predominantly at release sites around the somata of the bag cells, at the caudal end of the pleuroabdominal connectives. In contrast, the autocrine $\alpha$-, $\beta$-, and $\gamma$-bag-cell 
peptides, which are rapidly degraded and act primarily near their release sites, are more likely to be released from bag cell processes that terminate several millimeters up the connectives in the rostral direction, forming the "cuff" region. These peptides exert positive feedback interactions between the bag cell processes in the cuff region that contribute to the generation of the several-minute-long population burst that triggers egg laying (Brown and Mayeri, 1989). (3) The blood supply to the abdominal ganglion enters at its caudal pole and is directed rostrally, past the bag cell somata and the cuff region, continuing anteriorly in vascular channels along the length of the connectives. We hypothesize that by contracting and shortening the connectives in response to a bag cell burst, L7 causes the resistance of the vascular channels in the connectives to increase. This would have the effect of prolonging the time during which the autocrine peptides are active in the cuff, by slowing their rate of washout, thus ensuring that the mutual excitation of the bag cells proceeds effectively. Further work will be required to test this hypothesis directly.

\section{References}

Alevizos A, Koester J (1986) Identified gill motoneuron L7 of Aplysia is a multimodal motoneuron that also innervates the cardiovascular system. Soc Neurosci Abstr 12:499.

Alevizos A, Bailey CH, Chen M, Koester J (1989a) Innervation of vascular and cardiac muscle of Aplysia by multimodal motoneuron L7. J Neurophysiol 61:1053-1063.

Alevizos A, Weiss KR, Koester J (1989b) R15 activates respiratory pumping, motoneuron L7, and the hermaphroditic duct in Aplysia. Soc Neurosci Abstr 15:1140.

Alevizos A, Weiss KR, Koester J (1989c) The SCP containing R20 neurons modulate respiratory pumping in Aplysia. J Neurosci 9:30583071.

Alevizos A, Wciss KR, Kocstcr J (1991a) Synaptic actions of identified peptidergic neuron R15 in Aplysia. I. Activation of respiratory pumping. J Neurosci 11:1263-1274.

Alevizos A, Weiss KR, Koester J (1991b) Synaptic actions of identified peptidergic neuron R15 in Aplysia. III. Activation of the large hermaphroditic duct. J Neurosci 11:1282-1290.

Belchetz PE, Plant TM, Nakai Y, Keigh EJ, Knobil E (1978) Hypophysial responses to continuous and intermittent delivery of hypothalamic gonadotrophin-releasing hormone. Science 202:631-632.

Branton WD, Arch S, Smock T, Mayeri E (1978) Evidence for mediation of a neuronal interaction by a behaviorally active peptide. Proc Natl Acad Sci USA 75:5732-5736.

Brown RO, Mayeri E (1987) Central actions of R15, a putative peptidergic neuron in Aplysia. J Neurobiol 18:3-13.

Brown RO, Mayeri E (1989) Positive feedback by autoexcitatory neuropeptides in neuroendocrine bag cells of Aplysia. J Neurosci 9:14431451.

Brown RO, Pulst SM, Mayeri E (1989) Neuroendocrine bag cells of Aplysia are activated by bag cell peptide-containing neurons in the pleural ganglion. J Neurophysiol 61:1142-1152.

Camardo J, Proshansky E, Schacher S (1983) Identified Aplysia neurons form specific chemical synapses in culture. J Neurosci 3:2614 2620.

Carew TJ, Pinsker H, Rubinson K, Kandel ER (1974) Physiological and biochemical properties of neuromuscular transmission between identified motoneurons and gill muscle in Aplysia. J Neurophysiol 37:1020-1040.

Cobbs JS, Pinsker HM (1982a) Role of bag cells in egg deposition of
Aplysia brasiliana. I. Comparison of normal and elicited behaviors. J Comp Physiol 147:523-535.

Cobbs JS, Pinsker HM (1982b) Role of bag cells in egg deposition of Aplysia brasiliana. II. Contribution of egg movement to elicited behaviors. J Comp Physiol 147:537-546.

Coggeshall RE (1967) A light and electron microscope study of the abdominal ganglion of Aplysia californica. J Neurophysiol 30:12631287.

Frost WN (1987) Mechanisms contributing to short- and long-term sensitization in Aplysia. PhD dissertation, Columbia University.

Jacklet JW, Rine J (1977) Facilitation at neuromuscular junctions: contribution to habituation and dishabituation of the Aplysia gill withdrawal reflex. Proc Natl Acad Sci USA 74:1267-1271.

Koester J, Kandel ER (1977) Further identification of neurons in the abdominal ganglion of Aplysia using behavioral criteria. Brain Res 121:1-20.

Kupfermann I, Kandel ER (1969) Neuronal controls of a behavioral response mediated by the abdominal ganglion of Aplysia. Science 164: 847-850.

Kupfermann I, Carew TJ, Kandel ER (1974) Local, reflex and central commands controlling gill and siphon movements in Aplysia. J Neurophysiol 37:996-1019.

Kurokawa M, Kuwasawa K (1985) Electrophysiological studies on the branchial ganglion in the opisthobranch mollusks (Aplysia and Dolabella). J Comp Physiol 156:35-44.

Leonard JL, Padra M, Lukowiak K (1988) Gill arithmetic: interactions between identified neurons and their effect on evoked behaviors of Aplysia gill. Soc Neurosci Abstr 14:608.

Mayeri E, Rothman BS (1985) Neuropeptides and the control of egglaying behavior in Aplysia. In: Model neural networks and behavior (Selverston AI, ed), pp 205-301. New York: Plenum.

Mayeri E, Rothman BS, Brownell PH, Branton WD, Padgett L (1985) Nonsynaptic characteristics of neurotransmission mediated by egglaying hormone in the abdominal ganglion of Aplysia. I Neurosci 5: 2060-2077.

Painter SD, Rock MK, Nagle GT, Blankenship JE (1988) Peptide B induction of bag-cell activity in Aplysia: localization of sites of action to the cerebral and pleural ganglia. J Neurobiol 19:695-706.

Peretz B (1969) Central neuron initiation of periodic gill movements. Science 166:1167-1172.

Perlman AJ (1979) Central and peripheral control of siphon-withdrawal reflex in Aplysia californica. J Neurophysiol 42:510-529.

Rothman BS, Mayeri E, Brown RO, Yuan PM, Shively JE (1983) Primary structure and neuronal effects of $\alpha$-bag cell peptide, a second candidate neurotransmitter encoded by a single gene in bag cell neurons of Aplysia. Proc Natl Acad Sci USA 80:5753-5757.

Schacher S, Proshansky E (1983) Neurite regeneration by Aplysia neurons in dissociated cell culture: modulation by Aplysia hemolymph and the presence of the initial axonal segment. J Neurosci 3:24032413.

Sigvardt KA, Rothman BS, Brown RO, Mayeri E (1986) The bag cells of Aplysia as a multitransmitter system: identification of $\alpha$-bag cell peptide as a second neurotransmitter. J Neurosci 6:803-813.

Sossin WS, Sweet-Cordero A, Scheller RH (1990) Dale's hypothesis revisited: different neuropeptides derived from a common prohormone are targeted to different processes. Proc Natl Acad Sci USA 87: $4845-4848$.

Stuart DK, Strumwasser F (1980) Neuronal sites of action of a neurosecretory peptide, egg-laying hormone, in Aplysia californica. J Neurophysiol 43:499-519.

Umitsu Y, Matsumoto H, Koike H (1987) Active contraction of nerve bundle and identification of a nerve-contractor motoneuron in Aplysia. J Neurophysiol 58:1016-1034.

Weiss KR, Bayley H, Lloyd PE, Tenenbaum R, Gawinowicz Kolks MA, Buck L, Cropper EC, Rosen SC, Kupfermann I (1989) Purification and sequencing of neuropeptides contained in neuron R15 of Aplysia californica. Proc Natl Acad Sci USA 86:2913-2917. 